\title{
High-Resolution Marine Record of Climatic Change in Mid-latitude Chile during the Last 28,000 Years Based on Terrigenous Sediment Parameters
}

\author{
Frank Lamy, ${ }^{1}$ Dierk Hebbeln, and Gerold Wefer \\ Fachbereich Geowissenschaften, Universität Bremen, Postfach 3304 40, D-28334 Bremen, Germany
}

Received May 28, 1998

\begin{abstract}
Marine sediment cores from the continental slope off midlatitude $\mathrm{C}$ hile $\left(33^{\circ} \mathrm{S}\right)$ were studied with regard to grain-size distributions and clay mineral composition. The data provide a 28,000-yr ${ }^{14} \mathrm{C}$ accelerator mass spectrometry-dated record of variations in the terrigenous sediment supply reflecting modifications of weathering conditions and sediment source areas in the continental hinterland. These variations can be interpreted in terms of the paleoclimatic evolution of mid-latitude Chile and are compared to existing terrestrial records. Glacial climates $(28,000$ 18,000 cal yr B.P.) were generally cold-humid with a coldsemiarid interval between 26,000 and 22,000 cal yr B.P. The deglaciation was characterized by a trend toward more arid conditions. During the middle Holocene (8000- 4000 cal yr B.P.), comparatively stable climatic conditions prevailed with increased aridity in the Coastal Range. The late Holocene (4000- 0 cal yr B.P.) was marked by more variable paleoclimates with generally more humid conditions. Variations of rainfall in mid-latitude Chile are most likely controlled by shifts of the latitudinal position of the Southern W esterlies. Compared to the Holocene, the southern westerly wind belt was located significantly farther north during the last glacial maximum. Less important variations of the latitudinal position of the Southern Westerlies also occurred on shorter time scales. $\odot 1999$ University of Washington.
\end{abstract}

\section{INTRODUCTION}

Reconstructions of late Quaternary climatic changes in southern South America are primarily based on terrestrial data, including pollen analyses (e.g., Heusser, 1990; Villagrán, 1993), glaciological (e.g., Clapperton, 1993), and geomorphological-pedological (Veit, 1996) studies. Latitudinal shifts of the southern westerly atmospheric circulation system have been proposed as being responsible for the paleoclimatic variations recorded in these terrestrial datasets. Circulation during the last glacial maximum (LGM) is still controversial regarding whether the latitudinal shift was equatorward (e.g., Heusser, 1989) or poleward (e.g., Markgraf, 1989). More

\footnotetext{
${ }^{1}$ To whom correspondence should be addressed. E-mail: frank1@ allgeo.unibremen.de. Fax: $(++49) 4212183116$.
}

recently, modeling studies for the LGM paleoclimate of Patagonia (Hulton et al., 1994) and glacier fluctuations in southernmost Chile (Clapperton et al., 1995) support a moderate northward shift of the Westerlies.

Age control of the continental records is often problematic. Better stratigraphic control can be expected in marine sediments. The analysis of the terrigenous part of marine sediments provides an opportunity to examine modifications of weathering conditions and fluvial catchment areas of the continental hinterland. These variations can be interpreted in terms of terrestrial paleoclimatic changes recorded within the wellconfined stratigraphic framework of a marine sediment core. This approach has been successfully applied to reconstruct late Quaternary climatic changes in northern Chile $\left(27.5^{\circ} \mathrm{S}\right)$ on both Milankovitch (Lamy et al., 1998) and shorter time scales (J. Klump, unpublished data) of the last 120,000 yr.

In this paper we discuss the last 28,000 $\mathrm{yr}$, as recorded in two sediment cores off Valparaiso, Chile $\left(33^{\circ} \mathrm{S}\right)$. High sedimentation rates and a robust age control, based on ${ }^{14} \mathrm{C}$ accelerator mass spectrometry (AMS) dating, allow a detailed reconstruction of glacial and Holocene climates and a comparison with terrestrial records.

\section{STUDY AREA}

The two analyzed sediment cores were taken from the continental margin off mid-latitude Chile at approximately $33^{\circ} \mathrm{S}$ (Fig. 1). This area is characterized by a narrow shelf (10 to 20 $\mathrm{km}$ wide) and a moderate to steep continental slope. One core station is located in the southern part of the Valparaiso Basin, the second approximately $60 \mathrm{~km}$ farther south on the continental slope.

The oceanography of the study area is controlled by two northward-flowing surface currents: the Humboldt Current and the Chilean Coastal Current (Fig. 1). Separated from the Humboldt Current (Subantarctic Surface Water) by the polewardflowing Peru Chile Countercurrent (Subtropical Surface Water), the Chilean Coastal Current consists of a narrow band of comparatively low-salinity water from the southern Chilean fjord region and is part of the coastal upwelling system (Strub 


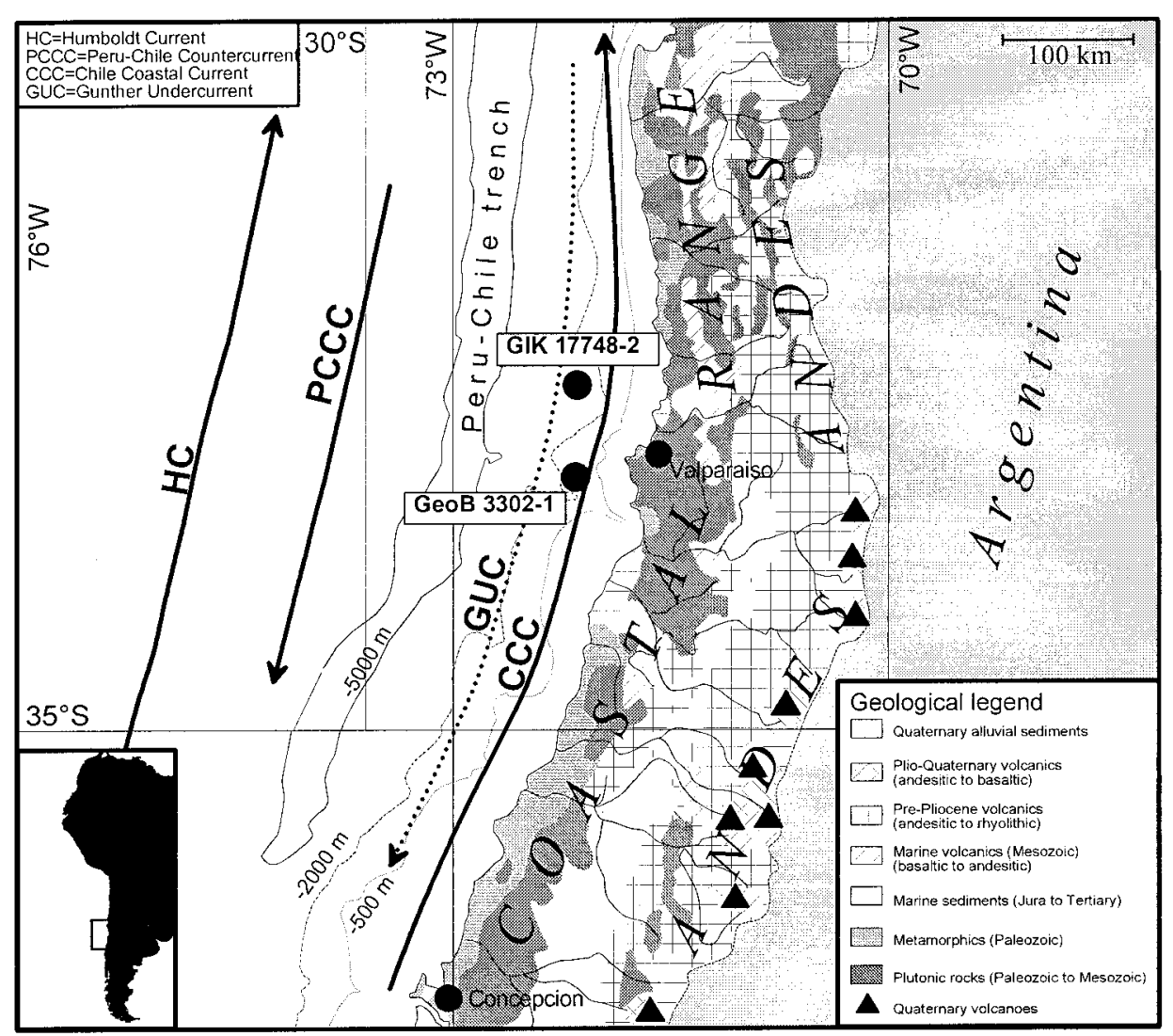

FIG. 1. Map of mid-latitude Chile and the adjacent southeastern Pacific Ocean showing location of cores and principal oceanographic features (after Strub et al., 1998). Superimposed geologic map is based on Thornburg and Kulm (1987).

et al., 1998). The surface water masses are underlain by the Gunther Undercurrent (ca. 100-300 m water depth) (Fig. 1), which consists of Equatorial Subsurface Water flowing south (e.g., Shaffer et al., 1995). Deeper currents include equatorward-flowing Antarctic Intermediate Water (ca. 400$1200 \mathrm{~m}$ water depth) underlain by southward-flowing Pacific Deep Water.

The physiography of the continental hinterland is dominated by the Coastal Range and the Andes (Fig. 1). The Coastal Range consists primarily of plutonic rocks, including mainly Mesozoic intermediate calc-alkaline lithologies but, especially in the vicinity of Valparaiso, Paleozoic rocks also occur; these are more alkaline in composition (Zeil, 1986; Thornburg and Kulm, 1987). Subordinately, Upper Cretaceous to Tertiary marine sediments, Mesozoic marine volcanics, and Paleozoic metamorphic rocks can be found within the Coastal Range (Fig. 1). The geology of the Andes is characterized by abundant volcanic rocks that can be divided into pre-Pliocene rhyolithic to andesitic ignimbrites and Pliocene-Quaternary andesitic rocks and tephra forming high stratovolcanoes up to $6000 \mathrm{~m}$ (Zeil, 1986).

Mid-latitude Chile is characterized by a semiaridmediterranean-type climate controlled by the seasonal influence of the Southern Westerlies. Precipitation values at $33^{\circ} \mathrm{S}$ range between $400 \mathrm{~mm} / \mathrm{yr}$ at the coast (Valparaiso) and $>1000$ $\mathrm{mm} / \mathrm{yr}$ in the high Andes (Miller, 1976). To the north, precipitation declines, whereas farther south significantly higher values, and lower seasonality, occur in both coastal and mountain areas.

Modern sediments on the continental slope in the area of $33^{\circ} \mathrm{S}$ are primarily supplied by rivers, without significant eolian sediment input (Lamy et al., 1998). The northern core site is influenced by the Río Aconcagua, which has very low fluvial discharge values $\left(1 \mathrm{~km}^{3} / \mathrm{yr}\right.$; Milliman et al., 1995). The southern core is located off the mouth of the Río Maipo, with higher discharge values $\left(3.2 \mathrm{~km}^{3} / \mathrm{yr}\right.$; Milliman et al., 1995). Both rivers originate in the Andes and cross the Coastal Range in their lower course. The geology of the two drainage basins is comparable.

\section{MATERIAL AND METHODS}

Gravity core GIK $17748-2\left(32^{\circ} 45^{\prime} \mathrm{S} ; 72^{\circ} 02^{\prime} \mathrm{W}\right.$, water depth $2545 \mathrm{~m}$, core length $383 \mathrm{~cm}$ ) was recovered from the Valparaiso basin during German R/V Sonne cruise SO 80 (Stoffers et al., 1992). The sediment consists primarily of light-brown to olive clayey silts and silty clays. Three distinct sandy turbidite layers are present. Carbonate contents range from approxi- 
mately 2 to $18 \mathrm{wt} \%$ (Marchant, 1997). For the examination of terrigenous sediment parameters, the core was sampled at $5-\mathrm{cm}$ intervals $(3-178 \mathrm{~cm}$ core depth) and at $10 \mathrm{~cm}$ below $178 \mathrm{~cm}$ depth.

Gravity core GeoB $3302-1\left(33^{\circ} 13^{\prime} \mathrm{S} ; 7^{\circ} 06^{\prime} \mathrm{W}\right.$, water depth $1498 \mathrm{~m}$, core length $412 \mathrm{~cm}$ ) was taken from the continental slope during R/V Sonne cruise SO 101-3 (Von Huene et al., 1995), and was opened and described during cruise SO 102 (Hebbeln et al., 1995). Sediments principally consist of olive to olive-brown clayey silts. Carbonate contents are minor (5 to 11 wt $\%$; unpublished data). Samples were taken at 5-cm intervals.

\section{Grain-Size Determinations}

Grain-size analyses were performed on the carbonate and the organic-matter-free sediment, removed by $10 \%$ acetic acid and $3.5 \%$ hydrogen peroxide, respectively. The sediment was split into three fractions by wet sieving (sand fraction $>63 \mu \mathrm{m}$ ) and Stokes' law settling using Atterberg tubes (silt $=2-63 \mu \mathrm{m}$ and clay fraction $=<2 \mu \mathrm{m}$ ). The settling procedure was repeated 8-12 times; coagulation of clay particles was avoided by adding a $0.1 \%$ sodium polyphosphate solution. The silt fraction was further analyzed by measurements with a Micromeritics SediGraph 5100 providing a high-resolution grain-size distribution in steps of 0.1 phi. The operation of the SediGraph is based on the X-ray scanning of a settling suspension assuming Stokes' law settling (e.g., Stein, 1985).

\section{Clay Mineral Analysis}

Clay mineralogy was determined by X-ray diffraction of the carbonate-free Mg-saturated clay fraction $(<2 \mu \mathrm{m})$ following standard procedures after Petschick et al. (1996). The analysis was performed on oriented mounts with a Philips PW 1820 diffractometer using $\mathrm{CoK} \alpha$ radiation $(40 \mathrm{kV}, 40 \mathrm{~mA})$. Each sample was measured three times: (1) under dry air conditions (scans from $2^{\circ}$ and $40^{\circ} 2 \theta$; step size of $0.02^{\circ}$ ), (2) after ethylene glycol solvation $\left(2^{\circ}-40^{\circ} 2 \theta ; 0.02^{\circ}\right)$, and (3) under ethylene glycol solvation $\left(28^{\circ}\right.$ and $\left.30.5^{\circ} 2 \theta ; 0.005^{\circ}\right)$. The latter was run as a slow scan in order to distinguish the 3.54/3.58 $\AA$ kaolinite/ chlorite double peak.

Relative percentages of the four main clay mineral groups (smectite, illite, chlorite, and kaolinite) were estimated by weighting integrated peak areas of characteristic basal reflections in the glycolated state with the empirical factors of Biscaye (1965). Crystallinity and composition of illite were assessed by measuring the half height width (HHW) of the 10 $\AA$ peak and the intensity ratio of the 5 and $10 \AA$ illite peaks (Esquevin, 1969), respectively. Smectite crystallinity was measured as the integral breadth (IB) of the glycolated $17 \AA$ smectite peak, which represents the breadth $\left(\Delta^{\circ} 2 \theta\right)$ of a rectangle of the same area and height as the peak.

The reproducibility of the measured clay mineralogical parameters was tested by repeated measurements of independently prepared mounts of the same samples. Relative errors of clay mineral contents are $\pm 6.5 \%$. Crystallinity and $5 / 10 \AA$ peak intensity ratio measurements are correct within a relative margin of \pm 5.2 and $\pm 6.7 \%$, respectively.

\section{Dating Methods}

The stable oxygen isotope composition of shells of the planktic foraminifera Neogloboquadrina pachyderma (dex.) was measured with a Finnigan MAT 251 mass spectrometer. Twenty individual shells $(>212 \mu \mathrm{m})$ were picked for each measurement. The isotopic composition of the carbonate sample was measured on the $\mathrm{CO}_{2}$ gas evolved by treatment with phosphoric acid at a constant temperature of $75^{\circ} \mathrm{C}$. The ratio of ${ }^{18} \mathrm{O} /{ }^{16} \mathrm{O}$ is given in parts per thousand relative to the PDB standard. A working standard (Burgbrohl $\mathrm{CO}_{2}$ gas) was used for measurement of the isotopic ratios of the samples NBS 18, 19 , and 20 of the National Bureau of Standards. Analytical standard deviation is about $\pm 0.07 \%$ PDB (Isotope Lab, Bremen University).

${ }^{14} \mathrm{C}$ AMS dates were obtained for $10 \mathrm{mg}$ carbonate (only shells of N. pachyderma) at the Leibniz Laboratory (University of Kiel, Germany; Nadeau et al., 1997) and the Center for Isotope Research (Groningen, Netherlands). All ages are corrected for ${ }^{13} \mathrm{C}$ and for a reservoir age of $400 \mathrm{yr}$ (Bard, 1988). The ${ }^{14} \mathrm{C}$ ages were converted to calendar years after the method of Bard et al. (1993).

\section{CHRONOLOGY}

The stratigraphy of core GIK 17748-2 (Marchant, 1997) is based on six ${ }^{14} \mathrm{C}$ AMS dates and linear interpolation between the age control points (Table 1). The sediment surface, with a modern age, is set to $-13 \mathrm{~cm}$, as the comparison with samples of a boxcorer indicates that the uppermost $13 \mathrm{~cm}$ of the core is missing (Stoffers et al., 1992). Additionally, three turbiditic layers $(9-16,47-54$, and $160-177 \mathrm{~cm})$ are assumed to be geologically "instantaneous" and were subtracted from the sedimentary sequence. Supported by two AMS dates immediately above and below the older turbidite layer, erosional effects can be excluded. The same is assumed for the two younger turbidite layers. The age of the core base is approximately 15,600 cal yr B.P. Sedimentation rates vary between approximately 7 and $20 \mathrm{~cm} / 1000 \mathrm{yr}$ for the Holocene section and are significantly higher during the deglaciation (Fig. 2).

The age model of core GeoB 3302-1 is also principally based on AMS dates (Table 1). Additionally, the $\delta{ }^{18} \mathrm{O}$ isotope record was correlated with that for core GIK 17748-2 for the uppermost sample of the core (Fig. 2). Between the seven age control points (Table 1), a linear interpolation was applied. For the lowermost part of the core the sedimentation rate between the two oldest AMS dates was extrapolated. The core is estimated to cover the interval 9600 to 28,000 cal yr B.P. Sedimentation rates are rather low, varying between 5 and $6 \mathrm{~cm} /$ $1000 \mathrm{yr}$ in the upper part of the core, which represents the 
TABLE 1

Age Control Points of Core GIK 17748-2 and GeoB 3302-1 Mainly Based on ${ }^{14} \mathrm{C}$ AMS Dating of Planktic Foraminifera ( $N$. pachyderma) Performed at the Leibniz Laboratory (U niversity of K iel, Germany) and the Center for Isotope R esearch (G roningen, Netherlands)

\begin{tabular}{ccccc}
\hline $\begin{array}{c}\text { Laboratory } \\
\text { number }\end{array}$ & $\begin{array}{c}\text { Core depth } \\
(\mathrm{cm})\end{array}$ & $\begin{array}{c}{ }^{14} \text { C AMS age } \\
(\text { yr B.P. })\end{array}$ & $\begin{array}{c} \pm \text { Err. } \\
(\mathrm{yr})\end{array}$ & $\begin{array}{c}\text { Calibrated age } \\
(\mathrm{cal} \text { yr B.P. })\end{array}$ \\
\hline
\end{tabular}

GIK 17748-2

$\begin{array}{lrrrr}\text { GrA } 1095 & 69 & 3760 & 40 & 4160 \\ \text { GrA } 1096 & 101 & 6890 & 40 & 7750 \\ \text { GrA } 3805 & 128 & 9650 & 80 & 10,700 \\ \text { GrA } 1097 & 156 & 10,520 & 50 & 12,210 \\ \text { GrA } 1098 & 185 & 11,200 & 50 & 13,050 \\ \text { GrA } 1099 & 341 & 12,890 & 60 & 15,140\end{array}$

GeoB 3302-1

\begin{tabular}{lrrrr} 
& 3 & & & $9790^{b}$ \\
KIA 4050 & 18 & 11,030 & 160 & 12,840 \\
KIA 4049 & 48 & 14,950 & 120 & 17,700 \\
KIA 4044 & 68 & 15,200 & 130 & 18,010 \\
KIA 4043 & 103 & 16,660 & 150 & 19,820 \\
KIA 4042 & 133 & 17,450 & 170 & 20,800 \\
KIA 4041 & 178 & 18,590 & 180 & 22,210 \\
KIA 4040 & 233 & 19,700 & 210 & 23,590 \\
\hline
\end{tabular}

Note. The ${ }^{14} \mathrm{C}$ ages were corrected for a reservoir effect of 400 years (Bard, 1988) and calibrated using the method of Bard et al. (1993).

${ }^{a}$ GrA, Groningen; KIA, Kiel.

${ }^{b}$ Correlation of $\delta^{18} \mathrm{O}$ isotope record to GIK 17748-2.

earliest Holocene and the deglaciation. During the last glaciation, sedimentation rates were high and generally in the range of 20 to $40 \mathrm{~cm} / 1000 \mathrm{yr}$ (the "spike" at ca. 18,000 cal yr B.P. is an artefact due to the narrow spacing of the dates; Fig. 2).

\section{RESULTS}

\section{Grain-Size Data}

Both cores (GIK 17748-2 and GeoB 3302-1) primarily consist of clayey silts. Sediments are comparatively coarse grained in the oldest part of GeoB 3302-1 (Fig. 3). Grain size becomes finer toward 26,000 cal yr B.P. Between 26,000 and 24,000 cal yr B.P., silt/clay ratios are higher again. Both silt/clay ratios and medians of the silt fraction indicate rather constant finegrained sediments throughout the interval from 23,000 to 17,500 cal yr B.P. (Fig. 3).

Grain-size data of core GeoB 3302-1 exhibit a general coarsening trend from 17,500 cal yr B.P. toward the early Holocene, concomitant with a significant decrease in the sedimentation rate (Figs. 2 and 3). The trend is interrupted by an interval of finer grain sizes about 15,000 cal yr B.P. (Fig. 3). The coarsening trend cannot be observed in core GIK 17748-2. In core GIK 17748-2, silt/clay ratios of the bulk sediment are high and significantly more variable during the deglaciation. Medians also reveal a high degree of variability (Fig. 3). During this time span, sedimentation rates were extremely high (Fig. 2). We assume that this is due to resedimentation processes that may have been caused by the postglacial sea-level rise, resulting in a reworking of sediment stored on the continental shelf. This is also indicated by increased abundances of redeposited benthic foraminifera (Marchant, 1997).

At the beginning of the Holocene, silt/clay ratios in GIK 17748-2 are in the range of those from GeoB 3302-1, and silt fractions are slightly finer grained (Fig. 3). During the Holocene, silt/clay ratios generally exhibit a trend toward finer grain sizes, especially in the early Holocene. The grain-size distributions of the silt fraction show similar trends (Fig. 3).

\section{Clay Mineralogy}

Relative contents of the main clay mineral groups, crystallinities of smectite and illite, and illite $5 / 10 \AA$ peak intensity
$\delta^{18} \mathrm{O}(\%$ vs. PDB)
of $N$. pachyderma (dex.)
Sedimentation-rate (cm/1000 yr)
$\begin{array}{lllllllll}2.0 & 1.5 & 1.0 & 0.5 & 0.0 & 0 & 1020 & 3040 & 5060708090100\end{array}$

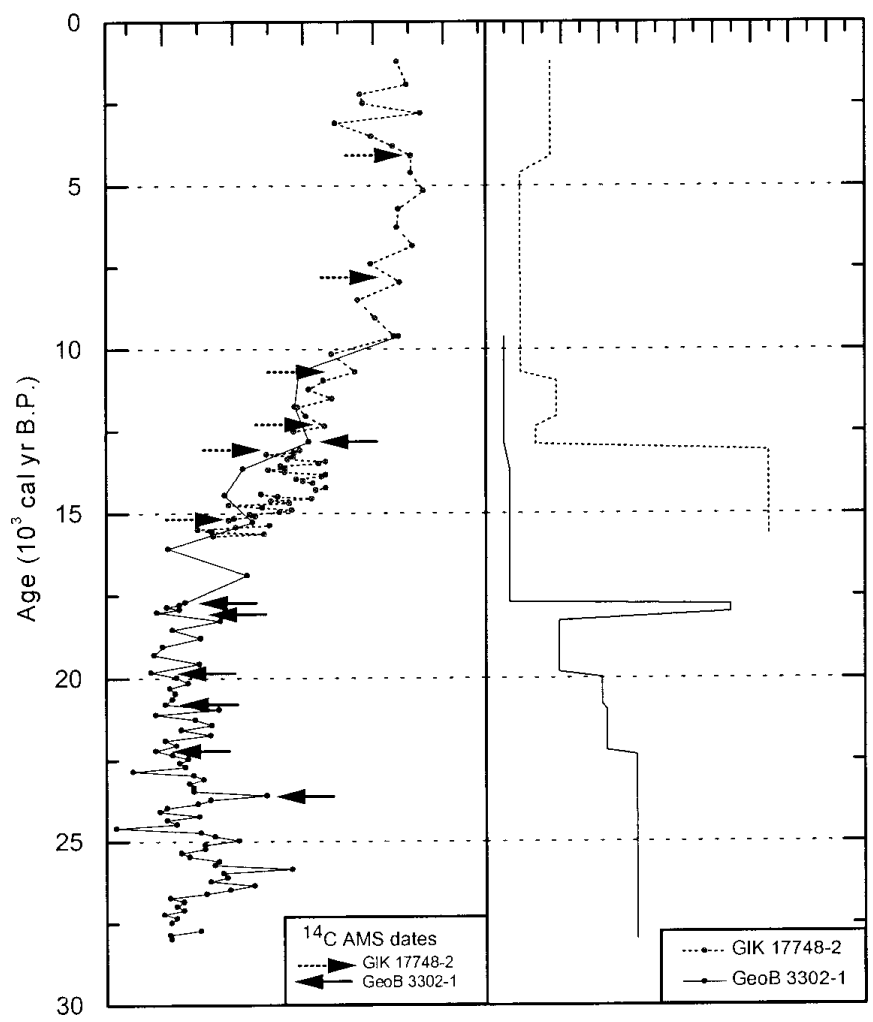

FIG. 2. Stratigraphy of cores GIK 17748-2 and GeoB 3302-1. The age models are primarily based on ${ }^{14} \mathrm{C}$ AMS dates and interpolation between these age-control points. The $\delta^{18} \mathrm{O}$ record of $N$. pachyderma (dex.) of GeoB 3302-1 has been correlated to that of GIK 17748-2 at the top of GeoB 3302-1. Sedimentation rates for both cores are plotted to the right. 


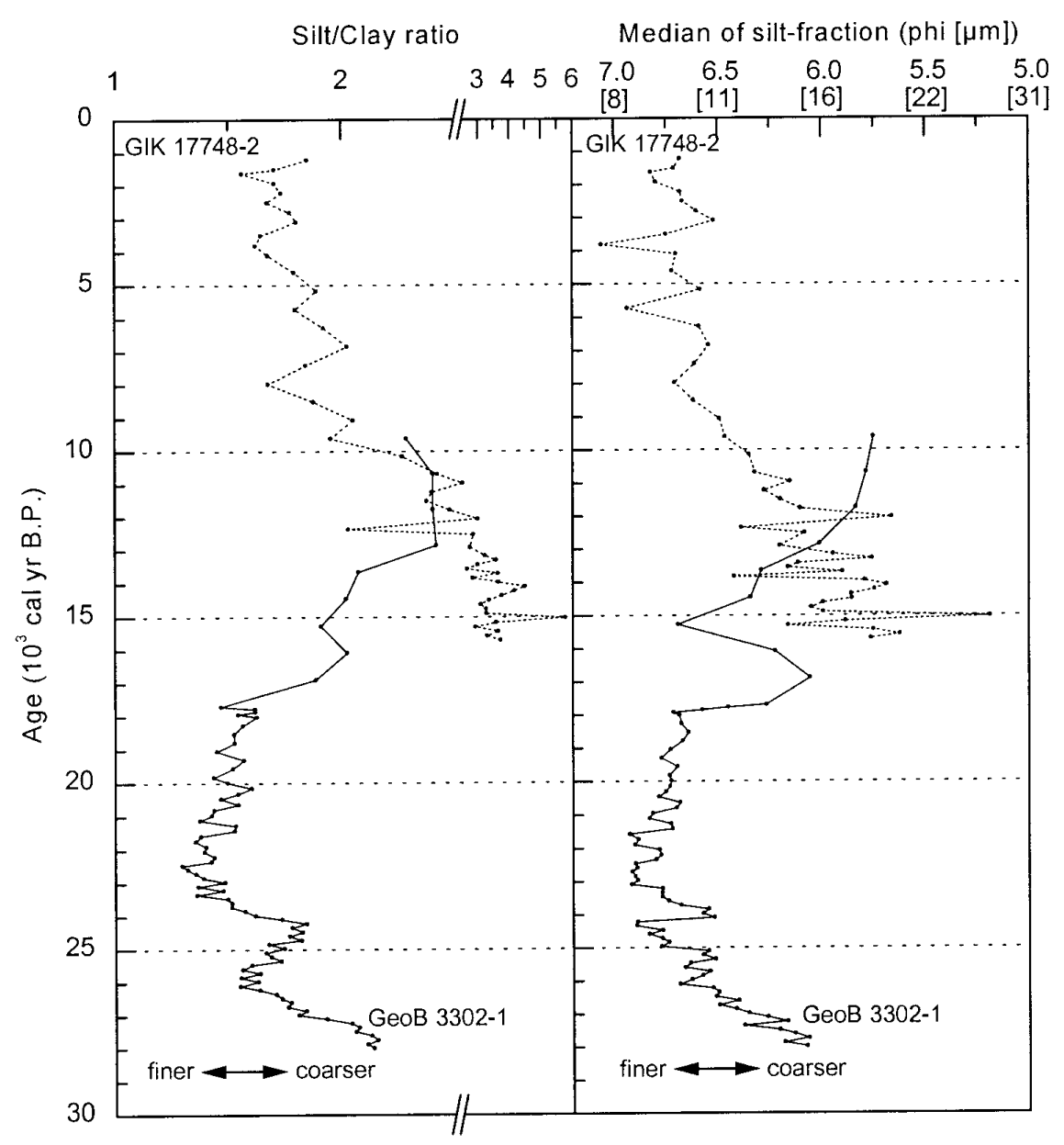

FIG. 3. Bulk grain size of carbonate-free sediment, represented by the silt/clay ratio and median of silt fraction (note axis break in left panel).

ratios reveal a distinct temporal evolution (Fig. 4). Both sediment cores are dominated by smectite, followed by chlorite and illite. Kaolinite only occurs in minor amounts $<10 \%$ ) and shows no significant temporal pattern (Fig. 4g). Smectite contents are comparatively low (30-35\%) about 27,000 cal yr B.P. The amount of smectite increases to $35-40 \%$ during the interval 26,000-22,000 cal yr B.P. and diminishes again to 30$35 \%$ between 22,000 and 18,000 cal yr B.P. (Fig. 4a). Chlorite shows a reverse pattern: generally low values from 26,000 to 22,000 cal yr B.P. (25-30\%), and higher values $(>30 \%)$ ca. 27,000 , as well as between 22,000 and 18,000 cal yr B.P. (Fig. 4f). Illite contents are rather constantly high during the whole glacial part of the core (approximately 26-30\%; Fig. 4c). During the deglaciation, smectite contents in core GeoB $3302-1$ increase from $30-35 \%$ to more than $45 \%$ (Fig. 4a). Illite contents decrease from $25-30 \%$ to about $20 \%$, and chlorite contents also diminish by approximately 5 to $10 \%$ (Figs. $4 \mathrm{c}$ and $4 \mathrm{f}$ ). For this time interval clay mineralogical parameters of core GIK 17748-2 have not been considered because the deglacial sedimentary sequence of this core is affected significantly by resedimentation processes. At the beginning of the
Holocene smectite contents in GIK 17748-2 were slightly higher, illite amounts similar, and chlorite and kaolinite contents lower than in GeoB 3302-1. However, the deglacial trend of increasing smectite and decreasing illite and chlorite contents continues throughout the early Holocene in GIK 17748-2. Smectite contents increase to nearly $60 \%$, while illite and chlorite amounts decrease to less than $20 \%$ (Figs. $4 \mathrm{a}, 4 \mathrm{c}$, and 4f). Between 8000 and 4000 cal yr B.P. clay mineral contents were relatively constant (i.e., comparatively high smectite, low illite and chlorite; Figs. 4a, 4c, and 4f). In the late Holocene (4000 cal yr B.P. to recent), our data show a comparatively high variability. Generally, mean smectite contents tend to decrease, whereas chlorite abundances especially are higher again (Figs. 4a and 4f).

Smectite as well as illite crystallinities (Figs. $4 \mathrm{~b}$ and $4 \mathrm{~d}$ ) are comparatively low, and illites are Al-rich (Fig. 4e) in the oldest part (28,000-26,000 cal yr B.P.). Between 26,000 and 22,000 cal yr B.P., crystallinities of both minerals are higher and the composition of illite is more Fe-Mg-rich. From 22,000 to 18,000 cal yr B.P. smectite crystallinities are lower. Mean illite crystallinities are also slightly lower, with a distinct peak of 


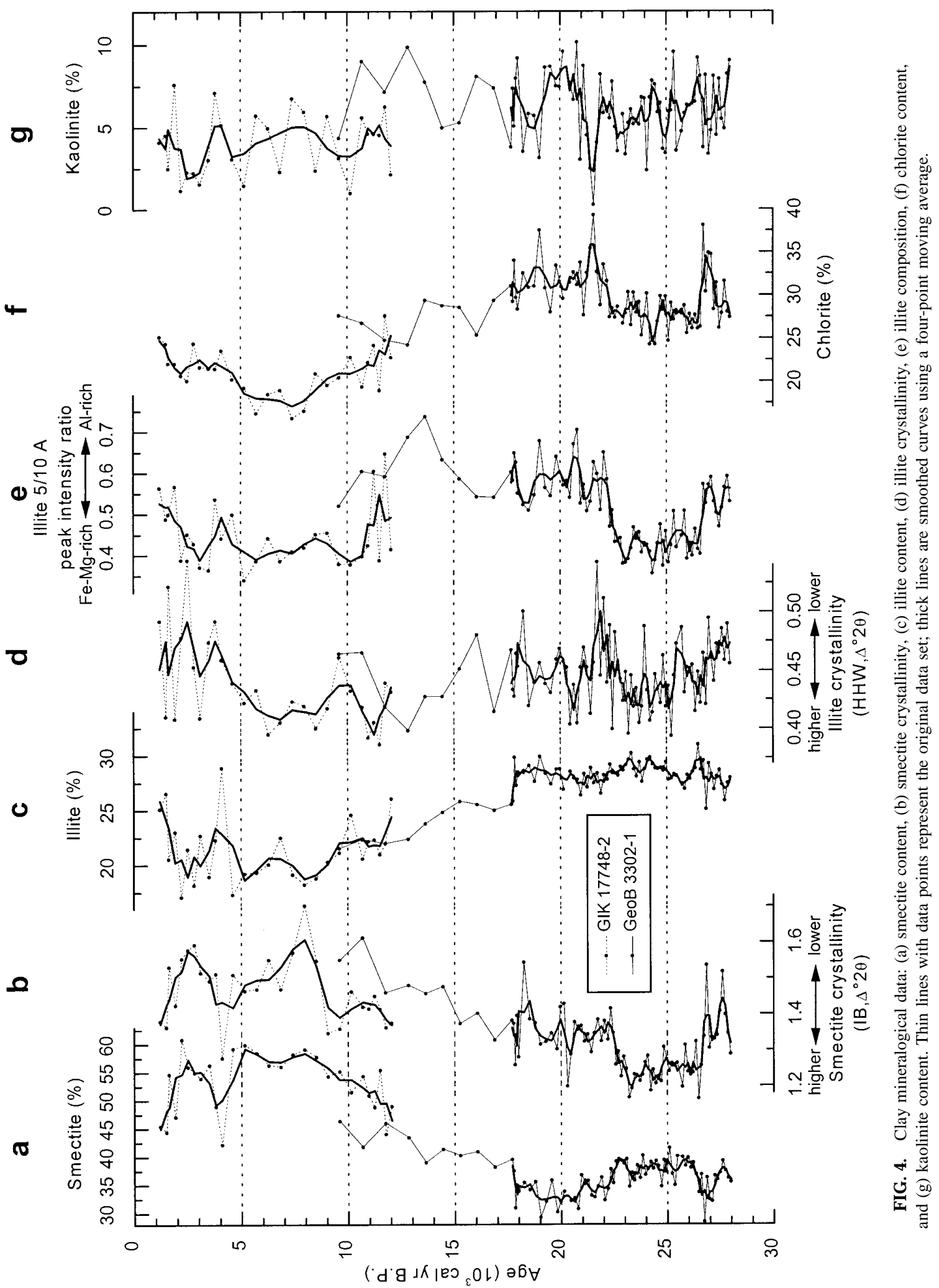


low crystallinities near 22,000 cal yr B.P. The composition of illite is relatively $\mathrm{Al}$-rich during this time span. During the deglaciation and the early Holocene, smectite crystallinities show a decreasing trend until approximately $8000 \mathrm{cal}$ yr B.P. Illite crystallinities reach a maximum between approximately 13,500 and 11,500 cal yr B.P. The illite $5 / 10 \AA$ peak intensity ratio reveals comparatively Al-rich compositions between 15,000 and 12,000 cal yr B.P. During the Holocene, illite crystallinities are constantly rather high and a Fe-Mg-rich composition predominates. The late Holocene can be characterized by generally lower crystallinities and a more Al-rich composition of illite. Similar to the other clay mineralogical parameters, a higher short-term variability can be noted during this interval. The smectite crystallinity is generally low during the Holocene.

\section{DISCUSSION}

\section{Proxies for Source Rocks and Continental Weathering Conditions}

The relative abundance of the three major clay mineral groups smectite, illite, and chlorite records the relative contribution of different source rocks. We assume that smectite in our sediment cores is primarily of continental origin. Low concentrations of opal and volcanic glass (deduced from X-ray powder diffraction measurements and smear slide data), both in the sediment cores and in surface samples of the area (Lamy et al., 1998), rule out any significant authigenic smectite input due to halmyrolytic weathering of volcanic glass within the marine environment.

On the continent, smectite is formed through chemical weathering processes, either by degradation of primary minerals or by neoformation using ions released in leaching solutions (e.g., Chamley, 1989). The amount of smectite formed within the source areas is strongly increased in volcanic rocks (e.g., Chamley, 1989). In the study area, volcanic rocks are nearly exclusively located in the Andes. Therefore, we interpret variations of smectite contents within the glacial to Holocene sequence primarily as a source rock signal. Higher smectite contents imply increased relative input of sediment from volcanic Andean source rocks (Fig. 1).

Illite and chlorite mainly result from physical weathering of crystalline (i.e., acidic plutonites for illite and basic igneous rocks for chlorite) and low-grade metamorphic rocks (e.g., Chamley, 1989). These source rocks can be found predominantly within the Coastal Range (Fig. 1). Thus, a higher abundance of these minerals in our sediment cores indicates a higher relative contribution of Coastal Range source rocks.

Variations of the relative source rock input are accompanied by changes in sedimentation rates. When sedimentation rates were low, as especially during the middle Holocene, clay mineral assemblages indicate the highest influence of Andean source rocks (Figs. 2 and 4). This can be explained best by reduced rainfall in mid-latitude Chile. But, as shown by modern precipitation patterns (Miller, 1976), rainfall within the Andes is significantly higher than in the Coastal Range. Therefore, clay mineral assemblages are dominated by the Andean source rock signal during drier climatic intervals.

Increased relative contribution of Coastal Range source rocks occurs concomitantly with higher sedimentation rates (Figs. 2 and 4). This indicates higher overall sediment input, pointing to more humid conditions. Increased precipitation in the presently semiarid environment should enhance sediment input from the lower reaches of rivers that lie within the Coastal Range. Our data therefore suggest a dilution of the Andean source rock signal by a higher relative contribution of Coastal Range sediment during more humid intervals.

Superimposed on the source rock signal, which most likely controls the difference between glacial and Holocene clay mineral assemblages and variations within the Holocene, changes in the amount of smectite produced by neoformation might have contributed to minor variations of smectite contents during the glaciation. The neoformation process is particularly important in semiarid climates with seasonal precipitation (Singer, 1984; Chamley, 1989). Smectite formed through neoformation is characterized by high crystallinities. Such smectite is especially abundant between 26,000 and 22,000 cal yr B.P., which may indicate temporary semiarid conditions in the Coastal Range, superimposed on the general more-humid glacial climate. Poorly crystallized smectite, which is dominant during the Holocene (Figs. 4b), is characteristic of humidtemperate climates (Chamley, 1989) and can be found in modern sediments off humid southern Chile (Lamy et al., 1998). This is consistent with the assumption that during the Holocene smectite is mainly derived from the volcanic Andes, where, due to the high altitude, more humid-temperate conditions can be expected.

Grain-size data of terrigenous sedimentary sequences undisturbed by resedimentation processes, as well as crystallinity and composition of clay minerals, can be used as proxies for continental weathering conditions, which strongly depend on the climate. Chemical weathering causes a more complete grain-size reduction of the source rock debris, as well as an opening of the structure and leaching of $\mathrm{Fe} / \mathrm{Mg}$ from the illite crystal lattice. This leads to finer grain sizes and lowcrystallized and Al-rich illites related to intervals of more intense chemical weathering. Correspondingly, coarser grain sizes and highly crystallized and Fe-Mg-rich illites are characteristic of relatively reduced chemical weathering (Singer, 1984; Chamley, 1989; Gingele, 1996). The chemical weathering intensity in subtropical to temperate climates, as in midlatitude Chile, is mainly determined by the amount of rainfall. Therefore, we use variations in chemical weathering intensities as an additional proxy for the reconstruction of precipitation changes in mid-latitude Chile. Our paleoclimatic interpretations thus are based on various independent proxies, i.e., grainsize data, clay mineralogy, and sedimentation rates. 


\section{Paleoclimatic Implications}

The temporal evolution of the proxy data allows the differentiation of time-spans with specific characteristics that can be interpreted in terms of paleoclimatic conditions. Figure 5 provides a summary of data, sedimentological interpretations, and paleoclimatic implications for each time interval.

\section{Last Glaciation (28,000-18,000 cal yr B.P.)}

Clay-mineral assemblages and sedimentation rates indicate increased fluvial sediment input and a relatively large supply of Coastal Range source rocks, implying generally more humid conditions during the glaciation. The only source of moisture in mid-latitude Chile is rainfall originating from the westerly precipitation belt (Miller, 1976). Therefore variations in rainfall indicate latitudinal movements of the Southern Westerlies. The direction of those shifts in southern South America have been controversial, especially with regard to the LGM. Based primarily on palynological data of Laguna de Tagua Tagua $\left(34^{\circ} \mathrm{S}\right)$, an equatorward displacement of cyclonic depressions related to the Southern Westerlies was suggested by Heusser (1990). On the other hand, generally cool, arid conditions have been proposed for mid-latitude Chile during the LGM, pointing to a poleward shift of the westerly precipitation belt (e.g., Markgraf, 1989). The data presented here, in addition to sedimentological studies off northern Chile $\left(27.5^{\circ} \mathrm{S}\right.$; Lamy et al., 1998), modeling studies of annual rainfall and snowline levels in central Chile and Patagonia (Caviedes, 1990; Hulton et al., 1994), and glacier fluctuations in southernmost Chile (Clapperton et al., 1995), support Heusser's view of a northward shift of the Southern Westerlies.

Superimposed on the generally humid conditions of the glaciation are less-pronounced, shorter-term paleohumidity changes, which are mainly indicated by varying intensities of continental chemical weathering. For the oldest part of the core (28,000-26,000 cal yr B.P.), relatively Al-rich and lowcrystallized illite point to a comparatively high chemical weathering intensity, which is also indicated by fining grain sizes. Clay mineral assemblages suggest less smectite neoformation as well as a high input of Coastal Range source rocks, culminating at 27,000 cal yr B.P. These data imply relatively humid conditions and a northern position of the Southern Westerlies. This interval coincides with a major advance of glaciers in Southern Chile (Lowell et al., 1995). The glacier advance is most likely due to a global cold pulse (Lowell et al., 1995), which could have forced the westerly wind belt northward, thereby causing higher rainfall in mid-latitude Chile. Leroux (1993) has shown that the intensity of cyclones in the Southern Westerlies is directly controlled by outbreaks of cold air from polar regions, and thus by high-latitude temperature.

From 26,000 to 22,000 cal yr B.P., temporary coarser grain sizes and $\mathrm{Fe}-\mathrm{Mg}$-rich, high-crystallized illites point to weaker chemical weathering. Higher smectite contents during this interval can be explained by smectite neoformation within the
Coastal Range, as indicated by higher smectite crystallinities. Smectite neoformation and reduced chemical weathering imply semiarid climatic conditions similar to those of today, rather than a year-round humid climate, as expected with a northward shift of the Southern Westerlies. However, sedimentation rates were high and smectite contents did not reach Holocene values, indicating that rainfall was still higher. We suggest that the Southern Westerlies shifted northward, but possibly less than during the LGM two millennia later.

Grain-size data and the composition of illite suggest that chemical weathering intensities were highest during the LGM (approximately 22,000-18,000 cal yr B.P.). This implies the most humid conditions and the northernmost position of the Southern Westerlies during this time interval, consistent with palynological data of mid-latitude Chile (e.g., Heusser, 1990) and paleoclimatic reconstructions based on pollen and beetle records from the southern Andes $\left(41^{\circ}-43^{\circ} \mathrm{S}\right.$ ) (Heusser et al., 1996). These data indicate cold, wet conditions for the interval $18,000-14,000{ }^{14} \mathrm{C}$ yr B.P. (ca. $21,500-16,500$ cal yr B.P.).

\section{Late-Glacial to Early Holocene (18,000-8000 cal yr B.P.)}

For the deglaciation, a notable change in clay mineral assemblages and grain-size parameters can be observed. Generally coarsening bulk and silt grain sizes indicate increasing physical weathering intensity, which can be interpreted as a trend toward more arid conditions. Increasing smectite contents indicate a growing relative influence of Andean source rocks coinciding with significantly lower sedimentation rates. This is consistent with decreasing rainfall and less dilution of the Andean source rock signal by inputs from the Coastal Range. Palynological studies show an overall increase in temperature and intervals of desiccation during the deglaciation in mid-latitude Chile (Heusser, 1990). In the southern Chilean Lake District and on Isla de Chiloé, pollen and glaciological data indicate a rapid warming after the final advance of glaciers between 14,890 and 13,900 ${ }^{14} \mathrm{C}$ yr B.P. (ca. 17,600-16,400 cal yr B.P.) (Lowell et al., 1995; Heusser et al., 1996).

Arid conditions in mid-latitude Chile prevailed at the Pleistocene/Holocene transition (Heusser, 1990; Villagrán and Varela, 1990; Veit, 1996). Enhanced aridity in this area might be related to the strength of the Southeast Pacific Anticyclone, which reached its maximum intensity during the deglaciation (Villagrán, 1993), possibly forcing the Southern Westerlies into a southern position. In addition, increasing temperatures in Antarctica might have reduced outbreaks of polar air, decreasing the intensity of mid-latitude cyclones (Leroux, 1993).

Proxy data for chemical weathering intensity indicate that superimposed on the trend toward more arid conditions during the deglaciation are short-term climatic events. However, the proxies do not reveal a homogenous picture: finer grain sizes (ca. 15,000 cal yr B.P.) and Al-rich illites (peaking at 13,500 cal yr B.P.) point to temporary higher chemical weathering intensity, whereas high illite crystallinities from approximately 


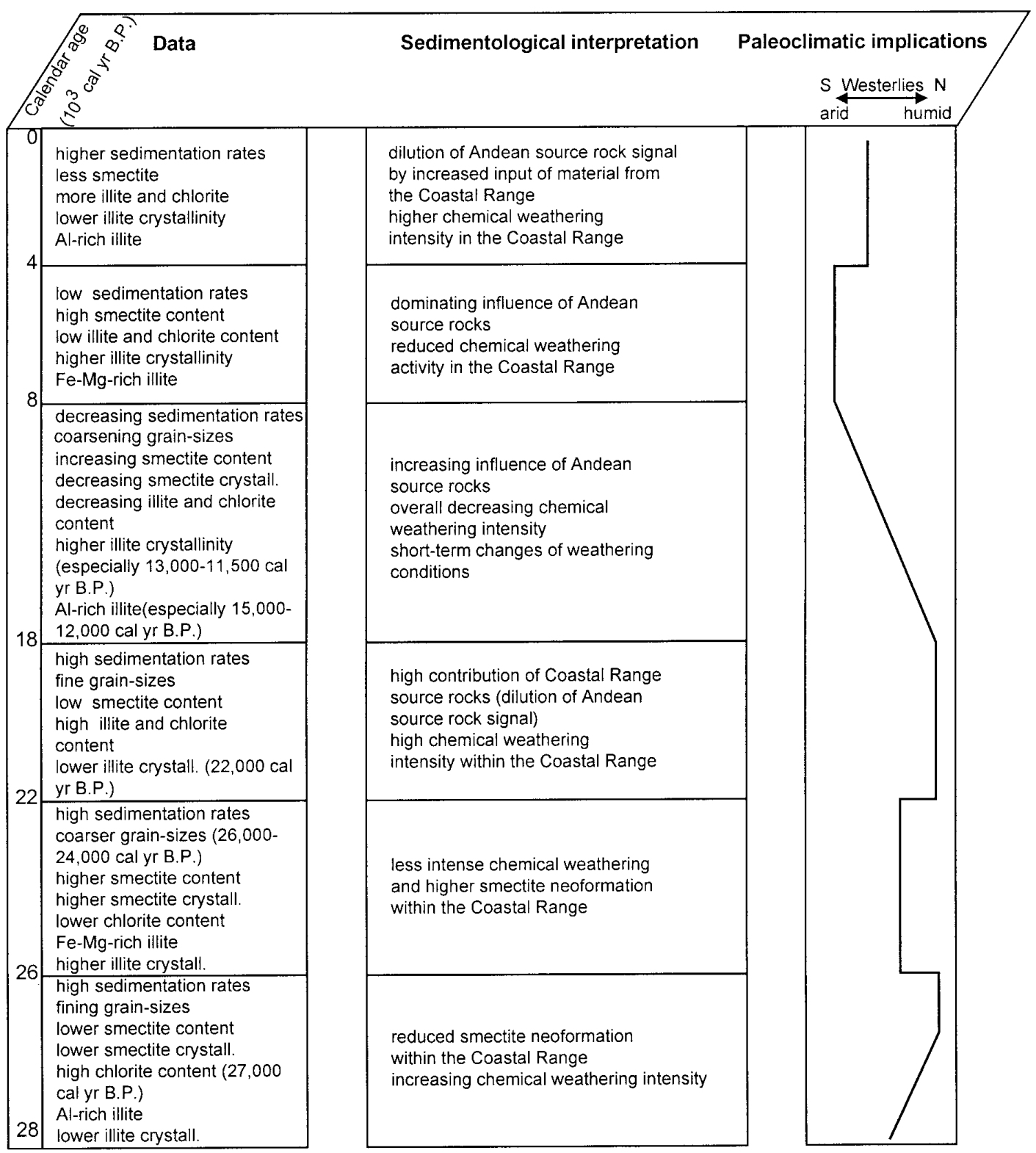

FIG. 5. Summary of data, sedimentological interpretations, and paleoclimatic implications for the last 28,000 years, based on the study of terrigenous sediments off mid-latitude Chile.

13,500 to $11,000 \mathrm{cal}$ yr B.P. point to reduced chemical weathering. These data imply short-term variations of paleohumidity during the deglaciation, which are also indicated by geomorphic (Veit, 1996) and palynological records (Villagrán and Varela, 1990) of mid-latitude Chile.

Farther south, in the southern Chilean Lake District and on Isla de Chiloé, pollen data show evidence of short-term temperature changes (i.e., a Younger Dryas cooling), whereas indications of glacier activity during this time span are absent (Lowell et al., 1995; Heusser et al., 1995; Heusser et al., 1996).

\section{Middle Holocene (8000-4000 cal yr B.P.)}

Grain-size and clay mineralogical data for the middle Holocene are relatively constant and imply increased physical weathering and a higher relative contribution of Andean source rocks. This can be interpreted as evidence of comparatively arid conditions, also indicated by low sedimentation rates.

Holocene paleoenvironmental reconstructions point to increased aridity for coastal areas and the Coastal Range in the early and middle Holocene (Villagrán and Varela, 1990; Veit, 1996). Compared to the glaciation, greater overall aridity im- 
plies a reduced influence of the westerly wind belt during the middle Holocene. The comparatively low variability in our data throughout the interval of $8000-4000$ cal yr B.P. can be interpreted as pointing to relatively stable climatic conditions, which have also been noted by Veit (1996) for the Coastal Range before $5000{ }^{14} \mathrm{C}$ yr B.P. (5600 cal yr B.P.).

\section{Late Holocene to Recent (4000-0 cal yr B.P.)}

Significantly more variable clay mineralogical parameters point to a higher variability of continental weathering conditions and sediment input, which may indicate a more changeable climate. Highly variable paleoenvironmental conditions in the late Holocene have also been derived from geomorphic studies (Veit, 1996) and the foraminiferal record of sediment core GIK 17748-2 (Marchant, 1997). The high variability in both terrestrial and marine records might be related to an increase in frequency and intensity of El Niño events (McGlone et al., 1992; Marchant, 1997) during the late Holocene. This could explain variable continental weathering conditions, as current rainfall variability is related to the Southern Oscillation (Ruttland and Fuenzalida, 1991).

Aside from the high variability in our data, a trend toward stronger chemical weathering and higher input of Coastal Range source rocks exists, indicating, overall, more humid conditions, consistent with palynological findings of Heusser (1990) and Villagrán and Varela (1990), and with a late Holocene glacier advance in the Andes at $29^{\circ} \mathrm{S}$ (Grosjean et al., 1998).

\section{CONCLUSIONS}

Glacial and Holocene variations in the terrigenous sediment input to the continental slope off mid-latitude Chile record changes in weathering intensities and relative source-rock contributions that can be interpreted paleoclimatically. These interpretations primarily imply precipitation changes. Variations of rainfall in mid-latitude Chile are most likely controlled by shifts of the latitudinal position of the Southern Westerlies.

The glacial-age sequence $(28,000-18,000$ cal yr B.P.) is generally characterized by a cold, humid climate, leading to enhanced chemical weathering intensity and higher sedimentation rates. The Andean source-rock signal is diluted by input of sediment from the Coastal Range. Reduced chemical weathering activity between 26,000 and 22,000 cal yr B.P. implies temporary more-arid conditions.

During late-glacial time and early Holocene (18,000-8000 cal yr B.P.), our data indicate increasing aridity. The middle Holocene interval (8000-4000 cal yr B.P.) was marked by a comparatively stable climate, with enhanced aridity in the Coastal Range leading to increased relative fluvial input from the Andes. Our data point to a higher climatic variability during the late Holocene (4000-0 cal yr B.P.) as well as more humid conditions.
The paleoclimatic study of terrigenous sediments off midlatitude Chile strongly supports Heusser's view of a significant northward shift of the Southern Westerlies during the LGM (e.g., Heusser, 1989). Additional smaller movements occurred during both the late-glacial interval and the Holocene, indicating that the latitudinal position of the Southern Westerlies also varied on shorter time scales.

\section{ACKNOWLEDGMENTS}

We thank the captain and crew of RV Sonne for their excellent help with coring and sampling operations during Sonne cruise SO 102 as well as P. Stoffers and K. Winn for retrieving core GIK 17748-2 during cruise SO 80. We thank B. Diekmann, G. Kuhn, R. Fröhlking, S. Janisch, and H. Rhodes at the Alfred Wegener Institute for Polar and Marine Research in Bremerhaven for providing analytical assistance, and M. Segl and B. Meyer-Schack for oxygen isotope measurements. We are grateful to C. M. Clapperton and an anonymous reviewer for prompt and constructive reviews. This study has been funded by the German Bundesministerium für Bildung und Forschung as part of the project CHIPAL (03G0102A).

\section{REFERENCES}

Bard, E. (1988). Correction of accelerator mass spectrometry ${ }^{14} \mathrm{C}$ ages measured in planktonic foraminifera: paleoceanographic implications. Paleoceanography 3, 635-645.

Bard, E., Arnold, M., Fairbanks, R. G., and Hamelin, B. (1993). ${ }^{230} \mathrm{Th}-{ }^{234} \mathrm{U}$ and ${ }^{14} \mathrm{C}$ ages obtained by mass spectrometry of corals. Radiocarbon $35,191-$ 199.

Biscaye, P. E. (1965). Mineralogy and sedimentation of recent deep-sea clay in the Atlantic Ocean and adjacent seas and oceans. Geological Society of America Bulletin 76, 803-832.

Caviedes, C. (1990). Rainfall variation, snowline depression, and vegetational shifts in Chile during the Pleistocene. Climatic Change 19, 94-114.

Chamley, H. (1989). "Clay Sedimentology.” Springer, Berlin.

Clapperton, C. M. (1993). Nature of environmental changes in South America at the Last Glacial Maximum. Palaeogeography, Palaeoclimatology, Palaeoecology 101, 189-208.

Clapperton, C. M., Sugden, D. E., Kaufman, D. S., and McCulloch, R. D. (1995). The last glaciation in Central Magellan Strait, southernmost Chile. Quaternary Research 44, 133-148.

Esquevin, J. (1969). Influence de la composition chimique des illites sur le cristallinité. Bulletin du Centre de Recherches de Pau-S.N.P.A. 3, 147-154.

Gingele, F. X. (1996). Holocene climatic optimum in Southwest AfricaEvidence from the marine clay mineral record. Palaeogeography, Palaeoclimatology, Palaeoecology 122, 77-87.

Grosjean, M., Geyh, M. A., Messerli, B., Schreier, H., and Veit, H. (1998). A late-Holocene $(<2600 \mathrm{BP})$ glacial advance in the south central Andes $\left(29^{\circ} \mathrm{S}\right)$, northern Chile. The Holocene 8, 473-479.

Hebbeln, D., Wefer, and cruise participants (1995). "Cruise Report of R/V SONNE Cruise 102, Valparaiso-Valparaiso, 9.5-28.6.95.” Universität Bremen, Bremen.

Heusser, C. J. (1989). Southern westerlies during the Last Glacial Maximum. Quaternary Research 31, 423-425.

Heusser, C. J. (1990). Ice age vegetation and climate of subtropical Chile. Palaeogeography, Palaeoclimatology, Palaeoecology 80, 107-127.

Heusser, C. J., Denton, G. H., Hauser, A., Andersen, B. G., and Lowell, T. V. (1995). Quaternary pollen records from the Archipiélago de Chiloé in the context of glaciation and climate. Revista Geológica de Chile 22, 25-46. 
Heusser, C. J., Lowell, T. V., Heusser, L. E., Hauser, A., Andersen, B. C., and Denton, G. H. (1996). Full-glacial-late-glacial palaeoclimate of the Southern Andes: Evidence from pollen, bettle and glacial records. Journal of Quaternary Science 11, 173-184.

Hulton, N., Sugden, D., Payne, A., and Clapperton, C. (1994). Glacier modeling and the climate of Patagonia during the Last Glacial Maximum. Quaternary Research 42, 1-19.

Lamy, F., Hebbeln, D., and Wefer, G. (1998). Late Quaternary precessional cycles of terrigenous sediment input off the Norte Chico, Chile $\left(27.5^{\circ} \mathrm{S}\right)$ and paleoclimatic implications. Palaeogeography, Palaeoclimatology, Palaeoecology 141, 233-251.

Lamy, F., Hebbeln, D., and Wefer, G. (1998). Terrigenous sediment supply along the Chilean continental slope: Modern latitudinal trends of texture and composition. Geologische Rundschau 87.

Leroux, M. (1993). The Mobile Polar High: a new concept explaining present mechanisms of meridional air-mass and energy exchanges and global propagation of paleoclimatic changes. Global and Planetary Change 7, 69-93.

Lowell, T. V., Heusser, C. J., Andersen, B. G., Moreno, P. I., Hauser, A., Heusser, L. E., Schlüchter, C., Marchant, D. R., and Denton, G. H. (1995). Interhemispheric correlation of Late Pleistocene glacial events. Science 269, 1541-1549.

Marchant, M. (1997). "Rezente und spätquartäre Sedimentation planktischer Foraminiferen im Peru-Chile Strom." Universität Bremen, Bremen.

Markgraf, V. (1989). Reply to C. J. Heusser's "Southern Westerlies" during the Last Glacial Maximum. Quaternary Research 31, 426-432.

McGlone, M. S., Kershaw, A. P., and Markgraf, V. (1992). El Niño/Southern Oscillation climatic variability in Australasian and South American paleoenvironmental records. In "El Niño: Historical and Paleoclimatic aspects of the Southern Oscillation" (H. F. Diaz, and V. Markgraf, Eds.), pp. 435-462.

Miller, A. (1976). The climate of Chile. In "World Survey of Climatology, Vol. 12" (W. Schwerdtfeger, Ed.), pp. 113-145. Elsevier, Amsterdam.

Milliman, J. D., Rutkowski, C., and Meybeck, M. (1995). "River Discharge to the Sea: A Global River Index (GLORI)" NIOZ, Texel, The Netherlands.

Nadeau, M. J., Schleicher, M., Grootes, P. M., Erlenkeuser, H., Gottolong, A., Mous, D. J. W., Sarnthein, J. M., and Willkomm, N. (1997). The LeibnizLabor AMS facility at the Christian-Albrechts University, Kiel, Germany. Nuclear Instruments and Methods in Physics Research 123, 22-30.
Petschick, R., Kuhn, G., and Gingele, F. (1996). Clay mineral distribution in surface sediments of the South Atlantic: Sources, transport and relation to oceanography. Marine Geology 130, 203-229.

Ruttland, J., and Fuenzalida, H. (1991). Synoptic aspects of the central Chile rainfall variability associated with the Southern Oscillation. International Journal of Climatology 11, 63-76.

Shaffer, G., Salinas, S., Pizarro, O., Vega, A., and Hormazabal, S. (1995). Currents in the deep ocean off Chile $\left(30^{\circ} \mathrm{S}\right)$. Deep-Sea Research 42, 425436.

Singer, A. (1984). The paleoclimatic interpretation of clay minerals in sediments-A review. Earth-Science Reviews 21, 251-293.

Stein, R. (1985). Rapid grain-size analyses of clay and silt fraction by Sedigraph 5000D: Comparison with Coulter Counter and Atterberg methods. Journal of Sedimentary Petrology 55, 590-615.

Stoffers, P., Hekinian, R., and cruise participants (1992). "Cruise Report Sonne 80a-Midplate III Oceanic Volcanism in the Southeast Pacific.” Universität Kiel, Kiel.

Strub, P. T., Mesias, J. M., Montecino, V., Ruttlant, J., and Salinas, S. (1998). Coastal ocean circulation off Western South America. In "The Global Coastal Ocean. Regional Studies and Syntheses" (A. R. Robinson and K. H. Brink, Eds.), pp. 273-314. Wiley, New York.

Thornburg, T., and Kulm, L. D. (1987). Sedimentation in the Chile Trench: Petrofacies and provenance. Journal of Sedimentary Petrology 57, 55-74.

Veit, H. (1996). Southern Westerlies during the Holocene deduced from geomorphological and pedological studies in the Norte Chico, Northern Chile (27-33 ${ }^{\circ}$ S). Palaeogeography Palaeoclimatology Palaeoecology 123, 107-119.

Villagrán, C. (1993). Una interpretatión climática del registro palinológico del último ciclo glacial-postglacial en Sudamérica. Bullitin de l'Institut François des études andines 22, 243-258.

Villagrán, C., and Varela, J. (1990). Palynological evidence for increased aridity on the Central Chilean coast during the Holocene. Quaternary Research 34, 198-207.

Von Huene, R., Corvalan, J., Korstgard, J., and cruise participants (1995). "Fahrtbericht zur Forschungsreise SO 101-Condor." GEOMAR, Kiel.

Zeil, W. (1986). "Südamerika.” Enke Verlag, Stuttgart. 